\title{
CONCERNING THE EFFECTS OF MAGNESIUM SULFATE ON RENAL FUNCTION, ELECTROLYTE EXCRETION, AND CLEARANCE OF MAGNESIUM ${ }^{1}$
}

\author{
By B. I. HELLER, J. F. HAMMARSTEN,2 AND F. L. STUTZMAN 3 \\ (From the Veterans Administration Hospital, and Departments of Medicine and Surgery, \\ University of Minnesota Medical School, Minneapolis, Minn.)
}

(Submitted for publication April 11, 1953; accepted May 22, 1953)

The effect of the parenteral administration of magnesium sulfate on the renal hemodynamics of normal dogs (1) and normal children (2) has been previously reported. However, no data are available concerning the effects of magnesium sulfate on the excretion of other electrolytes, nor have studies on the renal clearance of magnesium been reported. It is the purpose of this report to present such data.

\section{METHODS}

Studies of renal function, electrolyte excretion, and the clearance of magnesium were performed on six young men without evidence of cardiovascular or renal disease. The experimental subjects received a normal hospital diet which contained between 7 and 15 grams of sodium chloride daily. The experiments were performed in the basal state after adequate hydration by the oral ingestion of one liter of water 60 to 90 minutes before the study. Renal plasma flow was determined by the clearance of para-aminohippurate according to the method of Goldring and Chasis (3) and utilizing a constant injection syringe as previously described (4). The glomerular filtration rate was determined by the clearance of inulin utilizing the resorcinol method of Roe, Epstein, and Goldstein (5). Following a 45 minute equilibration period, three control observations of 15 minutes each were performed. Ten cc. of 25 per cent magnesium sulfate were then added to the sustaining solution and administered by constant intravenous injection. The magnesium sulfate was administered at the rate of 1.02 milli-equivalents of magnesium per minute. After a 45 minute period, the studies of renal function, electrolyte excretion, and magnesium clearance were repeated.

Sodium and potassium were determined by an internal standard Perkin-Elmer flame photometer. Control studies

1 Published with the approval of the Chief Medical Director. The statements and conclusions published by the authors are the result of their own study and do not necessarily reflect the opinion or policy of the Veterans Administration.

2 Present address: School of Aviation Medicine, Randolph Air Force Base, Texas.

3 Present address : U. S. Army Hospital, Bremerhaven, Germany. indicated that concentrations of magnesium exceeding those found in the urine in these experiments had no effect on the flame photometric determination of sodium or potassium. Chloride was determined by the method of Schales and Schales (6). Serum magnesium was determined by the molybdivanadate method of Simonsen, Westover, and Wertman (7). Urinary magnesium was determined by a similar method as modified by Stutzman (8).

\section{RESULTS}

The control values for renal hemodynamic, electrolyte excretion, and magnesium clearance studies are the averages of three consecutive periods. The values during the constant intravenous administration of magnesium sulfate are the averages of three consecutive periods beginning 45 minutes after the start of the infusion.

There was a significant decrease in mean renal plasma flow $(t=3.45, p 0.02-0.01)$ and in glomerular filtration rate $(t=5.98, p<0.01)$. Although the mean percentage change was slight, being 9.9 per cent for renal plasma flow and 8 per cent for glomerular filtration rate, both functions decreased in each patient. Since the statistical analysis was done by the method of paired controls $\left(t=\frac{\bar{x}}{\sqrt{\frac{s^{2}}{n}}}\right)$ and since the changes were all in the same direction, these changes in renal plasma flow and glomerular filtration rate are statistically significant. However, the degree of change does not imply physiologic significance. The filtration fraction increased in three patients and decreased in three. The clearance data are recorded in Table I.

The serum sodium, potassium, and chloride concentrations were unchanged by the administration of magnesium sulfate. An increase in the urinary sodium and chloride excretion and a decrease in potassium excretion occurred in each patient and 
TABLE I

Renal hemodynamic studies before and during magnesium sulfate infusion

\begin{tabular}{|c|c|c|c|c|c|c|}
\hline \multirow[b]{2}{*}{ Patient } & \multicolumn{2}{|c|}{$\begin{array}{l}\text { Renal plasma flow } \\
\text { (cc. per min.) }\end{array}$} & \multicolumn{2}{|c|}{$\begin{array}{l}\text { Glomerular filtration rate } \\
\text { (cc. per min.) }\end{array}$} & \multicolumn{2}{|c|}{$\begin{array}{l}\text { Filtration fraction } \\
\text { (per cent) }\end{array}$} \\
\hline & Control & $\begin{array}{c}\text { During } \\
\text { magnesium } \\
\text { sulfate }\end{array}$ & Control & $\begin{array}{c}\text { During } \\
\text { magnesium } \\
\text { sulfate }\end{array}$ & Control & $\begin{array}{c}\text { During } \\
\text { magnesium } \\
\text { sulfate }\end{array}$ \\
\hline $\begin{array}{l}\text { J. G. } \\
\text { P. M. } \\
\text { H. C. } \\
\text { L.S. } \\
\text { R. S. } \\
\text { D. D. }\end{array}$ & $\begin{array}{l}705 \\
614 \\
769 \\
852 \\
574 \\
723\end{array}$ & $\begin{array}{l}567 \\
556 \\
663 \\
832 \\
563 \\
638\end{array}$ & $\begin{array}{l}123 \\
130 \\
138 \\
141 \\
110 \\
116\end{array}$ & $\begin{array}{r}113 \\
119 \\
134 \\
132 \\
100 \\
99\end{array}$ & $\begin{array}{l}17.4 \\
21.1 \\
17.9 \\
16.5 \\
19.1 \\
14.6\end{array}$ & $\begin{array}{l}19.9 \\
21.0 \\
20.2 \\
15.8 \\
17.5 \\
15.5\end{array}$ \\
\hline $\begin{array}{c}\text { Mean } \\
\text { Per cent change }\end{array}$ & 706.2 & $\begin{array}{r}636.5 \\
-9.9\end{array}$ & 126.3 & $\begin{array}{l}116.2 \\
-8\end{array}$ & 17.7 & $\begin{array}{r}18.3 \\
+3.4\end{array}$ \\
\hline
\end{tabular}

the mean changes were statistically significant (sodium, $\mathrm{t}=3.64, \mathrm{p} 0.02-0.01$; chloride, $\mathrm{t}=$ 3.32 , $\mathrm{p} 0.05-0.02$; potassium, $\mathrm{t}=4.78, \mathrm{p}<0.01$ ). ministration of magnesium sulfate. The data for urinary electrolyte excretion are noted in Table II. The mean control serum magnesium concen-

TABLE II

Urine electrolyte excretion before and during magnesium sulfate infusion

\begin{tabular}{|c|c|c|c|c|c|c|}
\hline \multirow[b]{2}{*}{ Patient } & \multicolumn{2}{|c|}{$\begin{array}{c}\text { Urine sodium excretion } \\
\text { (micro-equisalents per min.) }\end{array}$} & \multicolumn{2}{|c|}{$\begin{array}{l}\text { Urine chloride excretion } \\
\text { (micro-equivalents per min.) }\end{array}$} & \multicolumn{2}{|c|}{$\begin{array}{l}\text { Urine potassium excretion } \\
\text { (micro-equivalents per min.) }\end{array}$} \\
\hline & Control & $\begin{array}{c}\text { During } \\
\text { magnesium } \\
\text { sulfate }\end{array}$ & Control & $\begin{array}{c}\text { During } \\
\text { magnesium } \\
\text { sulfate }\end{array}$ & Control & $\begin{array}{c}\text { During } \\
\text { magnesium } \\
\text { sulfate }\end{array}$ \\
\hline $\begin{array}{l}\text { J. G. } \\
\text { P. M. } \\
\text { H. C. } \\
\text { L. S. } \\
\text { R. S. } \\
\text { D. D. }\end{array}$ & $\begin{array}{l}302 \\
242 \\
197 \\
211 \\
197 \\
192\end{array}$ & $\begin{array}{l}431 \\
380 \\
423 \\
235 \\
299 \\
230\end{array}$ & $\begin{array}{l}332 \\
160 \\
177 \\
175 \\
205 \\
202\end{array}$ & $\begin{array}{l}415 \\
288 \\
362 \\
213 \\
279 \\
210\end{array}$ & $\begin{array}{r}110 \\
80 \\
110 \\
118 \\
79 \\
147\end{array}$ & $\begin{array}{l}77 \\
51 \\
66 \\
51 \\
55 \\
62\end{array}$ \\
\hline $\begin{array}{l}\text { Mean } \\
\text { Per cent change }\end{array}$ & 223.5 & $\begin{array}{c}333 \\
+48.9\end{array}$ & 208.5 & $\begin{array}{r}294.5 \\
+41.2\end{array}$ & 107.3 & $\begin{array}{r}60.3 \\
-43.8\end{array}$ \\
\hline
\end{tabular}

Analysis of urinary electrolyte excretion in the tration was $1.64 \mathrm{mEq}$. per liter. The clearance of individual periods revealed that the changes began magnesium was calculated from the usual clearin the first period of observation following the ad- ance formula. The mean control value for the

TABLE III

Renal clearance of magnesium

\begin{tabular}{|c|c|c|c|c|c|c|c|c|}
\hline \multirow[b]{4}{*}{ Patient } & \multicolumn{4}{|c|}{$\begin{array}{c}\text { Serum magnesium } \\
(m E q . \text { per liter })\end{array}$} & \multirow{2}{*}{\multicolumn{2}{|c|}{$\begin{array}{l}\text { Renal clearance of } \\
\text { magnesium } \\
\text { (cc. per min.) }\end{array}$}} & \multirow{2}{*}{\multicolumn{2}{|c|}{$\begin{array}{l}\text { Clearance magnesium ratio } \\
\text { Clearance inulin }\end{array}$}} \\
\hline & \multirow[b]{3}{*}{ Control } & \multicolumn{3}{|c|}{$\begin{array}{l}\text { During magnesium } \\
\text { administration }\end{array}$} & & & & \\
\hline & & & Period & & \multirow[b]{2}{*}{ Control } & \multirow{2}{*}{$\begin{array}{c}\text { During } \\
\text { magnesium } \\
\text { administration }\end{array}$} & \multirow[b]{2}{*}{ Control } & \multirow{2}{*}{$\begin{array}{c}\text { During } \\
\text { magneshum } \\
\text { administration }\end{array}$} \\
\hline & & 4 & 5 & 6 & & & & \\
\hline $\begin{array}{l}\text { J. G. } \\
\text { P. M. } \\
\text { H. C. } \\
\text { L. S. } \\
\text { R. S. } \\
\text { D. D. }\end{array}$ & $\begin{array}{l}1.69 \\
1.52 \\
1.49 \\
1.73 \\
1.68 \\
1.73\end{array}$ & $\begin{array}{l}2.18 \\
2.18 \\
2.07 \\
2.24 \\
2.19 \\
2.42\end{array}$ & $\begin{array}{l}2.45 \\
2.32 \\
2.23 \\
2.34 \\
2.32 \\
2.58\end{array}$ & $\begin{array}{l}2.60 \\
2.40 \\
2.41 \\
2.49 \\
2.35 \\
2.68\end{array}$ & $\begin{array}{l}6.36 \\
6.75 \\
3.98 \\
4.65 \\
5.79 \\
4.69\end{array}$ & $\begin{array}{l}18.2 \\
26.0 \\
31.8 \\
32.5 \\
24.2 \\
25.2\end{array}$ & $\begin{array}{l}.052 \\
.052 \\
.029 \\
.033 \\
.053 \\
.040\end{array}$ & $\begin{array}{l}.161 \\
.218 \\
.237 \\
.246 \\
.242 \\
.254\end{array}$ \\
\hline Mean & 1.64 & 2.21 & 2.37 & 2.49 & 5.37 & 26.3 & .043 & .226 \\
\hline
\end{tabular}


clearance of magnesium was $5.37 \mathrm{cc}$. per minute. The ratio of the clearance of magnesium to that of inulin was 0.043 during the control period, yielding a mean value for magnesium tubular reabsorption of 95.7 per cent. The serum magnesium concentration did not remain constant after the magnesium sulfate infusion was started. The mean values for the three post-magnesium periods were $2.21,2.37$, and $2.49 \mathrm{mEq}$. per liter. In view of these increasing serum concentrations, the clearance of magnesium during these periods could only be approximated. The mean approximate clearance for the last three periods was $26.3 \mathrm{cc}$. per minute. The mean ratio of magnesium to inulin clearance for these periods was 0.226 and mean tubular reabsorption of magnesium decreased to 77.4 per cent. The average urinary excretion of magnesium was 8.5 micro-equivalents per minute during the control periods and 64.6 micro-equivalents per minute during the infusion of magnesium sulfate. The data concerning magnesium are recorded in Table III.

\section{DISCUSSION}

The present concept of the action of magnesium sulfate upon the kidney is that the renal vascular bed participates in the generalized vasodilatation which follows the parenteral administration of magnesium $(1,2)$. Thus renal plasma flow and glomerular filtration rate may be maintained despite a drop in blood pressure, these results being explained by renal afferent arteriolar dilatation. The validity of this concept is supported by the observation that magnesium sulfate produces renal hyperemia, without significant changes in the glomerular filtration rate, in the hypertensive phase of acute glomerulonephritis (9).

It is to be noted that our experimental procedure differed from those previously reported since our control studies and studies during the administration of magnesium sulfate were performed consecutively. The total duration of each experiment was three to three and one-half hours. Under these experimental conditions, the intravenous administration of magnesium sulfate was associated with a slight but statistically significant decrease in renal plasma flow and glomerular filtration rate. No significant change in blood pressure was noted in any of the subjects.
The action of magnesium sulfate in causing an increase in the urinary excretion of sodium and chloride is of interest. Increased load is obviously not a factor since the serum concentration of these ions did not change and since there was actually a decrease in the glomerular filtration rate. Osmotic activity by the magnesium ion could not have played a role since the rate of urine excretion decreased in most of the experimental periods following the magnesium infusion. It is further to be noted that the excretion of potassium decreased at a time when sodium and chloride excretion were increasing. The mechanism responsible for these changes is unknown. The data presented are compatible with the hypothesis that magnesium, a divalent ion, may enter into a univalent ion exchange mechanism resulting in a decreased tubular reabsorption of sodium and increased reabsorption of potassium. However, the evidence is indirect, and it is possible that other mechanisms are involved.

It has been suggested that magnesium is excreted by the renal tubules (10). However, there are no previous observations in the literature relative to the clearance of magnesium. While the clearance of magnesium increases rapidly with increased magnesium loading, the values for urinary excretion in these experiments are far below those required to implicate tubular excretory processes as a mechanism in the renal clearance of magnesium. For example, at a serum magnesium concentration of $2.49 \mathrm{mEq}$. per liter. and a glomerular filtration rate of $116 \mathrm{cc}$. per minute, 289 micro-equivalents per minute would be excreted by filtration alone assuming no tubular reabsorption. At comparable values in our experiments, 64.6 micro-equivalents per minute were excreted. In order to test the hypothesis that tubular excretion of magnesium occurs, it would be necessary to increase the magnesium loading to levels that would probably be unsafe in human experiments. Since it has been demonstrated that magnesium is excreted by the aglomerular fish kidney (11), the possibility of the tubular excretion of magnesium by the human kidney must remain an open question. Experimental observations in patients with renal insufficiency and in animals, similar to those involving potassium excretion, may provide the answer. 


\section{SUMMARY AND CONCLUSIONS}

The constant, intravenous administration of magnesium sulfate to subjects without cardiovascular or renal disease was associated with a slight but significant decrease in renal plasma flow and glomerular filtration rate. There was an increased urinary excretion of sodium and chloride and a decreased excretion of potassium. The serum concentration of these electrolytes did not change. The mean renal clearance of magnesium in the basal state was $5.37 \mathrm{cc}$. per minute. This increased to $26.3 \mathrm{cc}$. per minute following the injection of magnesium. The data presented suggest that magnesium may be involved in an ion exchange mechanism.

\section{REFERENCES}

1. Harris, J. S., and DeMaria, W. J. A., Effects of magnesium sulfate on the renal dynamics of normal dogs. Am. J. Physiol., 1951, 166, 199.

2. Etteldorf, J. N., Clayton, G. W., Tuttle, A. H., and Houck, C. R., Renal function studies in pediatrics. II. Influence of magnesium sulfate on renal hemodynamics in normal children. Am. J. Dis. Child., 1952, 83, 301.

3. Goldring, W., and Chasis, H., Hypertension and hy- pertensive disease. Commonwealth Fund, New York, 1944.

4. Heller, B. I., and Jacobson, W. E., Renal hemodynamics in heart disease. Am. Heart J., 1950, 39, 188.

5. Roe, J. H., Epstein, J. H., and Goldstein, N. P., A photometric method for the determination of inulin in plasma and urine. J. Biol. Chem., 1949, 178, 839.

6. Schales, O., and Schales, S. S., Simple and accurate method for the determination of chloride in biological fluids. J.. Biol. Chem., 1941, 140, 879.

7. Simonsen, D. G., Westover, L. M., and Wertman, M., Determination of serum magnesium by molybdivanadate method for phosphate. J. Biol. Chem., 1947, 169, 39.

8. Stutzman, F. L., Studies in Magnesium Metabolism. A thesis submitted to the Graduate Faculty of the University of Minnesota, Minneapolis, 1952.

9. Etteldorf, J. N., and Tuttle, A. H., The effects of magnesium sulfate on renal function in children with acute glomerulonephritis. J. Pediat., 1952, 41, 524.

10. Hirschfelder, A., Effect of renal insufficiency upon plasma magnesium and magnesium excretion after ingestion of magnesium sulfate. J. Biol. Chem., 1934, 104, 647.

11. Bieter, R. N., Further studies concerning the action of diuretics upon the aglomerular kidney. J. Pharmacol. \& Exper. Therap., 1933, 49, 250. 